\title{
Evaluasi Kurikulum Pembelajaran Berbasis Kebutuhan Masyarakat: Studi pada Program Sarjana Hukum Ekonomi Syariah
}

\author{
Fauzul Hanif Noor Athief ${ }^{a)}$, Azhar Alam ${ }^{\text {b) }}$, Nurul Latifatul Inayatic) \\ a) Universitas Muhammadiyah Surakarta, $\underline{\text { https://orcid.org/0000-0002-4784-904X }}$ \\ b) Universitas Muhammadiyah Surakarta \\ c) Universitas Muhammadiyah Surakarta
}

\section{ABSTRAK}

Jumlah alumni program studi Hukum Ekonomi Syariah belum terlalu banyak yang dapat terserap sebagai praktisi industri. Salah satu faktor yang kemudian menjadi sorotan utama bagi lembaga penyedia pendidikan adalah kurikulum yang belum mampu menunjang alumninya untuk bisa terjun di profesi hukum. Berbagai penelitian terkait keterlibatan praktisi industri dalam pengembangan kurikulum yang mampu menambah daya serap alumni sebagai praktisi menjadi titik tolak penting. Penelitian ini berusaha untuk menyelesaikan masalah terkait apa saja mata kuliah yang dibutuhkan dalam sebuah kurikulum agar mampu membekali alumni dengan kompetensi yang cukup. Dengan menggunakan metode ANP yang mensyaratkan pakar sebagai responden, kami berusaha menyelesaikan persoalan tersebut. Jumlah responden yang digali opininya adalah 10 yang terdiri dari praktisi profesi hukum, lembaga keuangan syariah serta asosiasi profesi. Hasil dari penelitian ini menunjukkan bahwa Kompetensi Hukum adalah sorotan utama dari para pakar. Kemudian Bahasa Arab Dasar, Analisa Laporan Keuangan, Kajian Fatwa, Arbitrase serta Etika Profesi Hukum menjadi fokus terpenting untuk mata kuliah tambahan di luar kompetensi yang disepakati seluruh kampus. Kemudian untuk profil lulusan yang paling relevan dari 5 rumpun mata kuliah yang ada adalah Hakim. Terakhir, pengembangan yang perlu dilakukan untuk menghasilkan para lulusan tersebut adalah Perkuliahan.

\section{ABSTRACT}

There are only few numbers of Islamic Economic Law program graduates that have been absorbed as industry practitioners. One of main focus for educational providers is the inadequate curriculum to support its graduates to get involved at any legal profession. Various studies related to the involvement of industry practitioners in curriculum development that are able to increase the absorption of alumni as practitioners are important starting points. This study seeks to solve problems related to what courses are required in a curriculum in order to be able to equip alumni with sufficient competencies. By using the ANP method which requires an industry expert as a respondent, we try to solve this problem. The number of respondents whose opinions were extracted was 10 consisting of practitioners of the legal profession, Islamic financial institutions and professional associations. The results of this study indicate that Legal Competence is the main highlight of the experts. Then Basic Arabic, Financial Statement Analysis, Fatwa Studies, Arbitration and Professional Ethics in the Law became the most important focus for additional courses outside the competencies agreed upon by the entire campus. As for the graduate profile, the most relevant based on the courses offered is Judges. Finally, the development that needs to be done to produce these graduates is Class Lectures.

\section{KATA KUNCI}

Kurikulum; Hukum Ekonomi Syariah; Alumni; Analisis Proses Jaringan.

\section{KEYWORDS}

Curriculum; Islamic Economic Laws; Network Process Analysis. 


\section{A. Pendahuluan}

Ekosistem ekonomi syariah di Indonesia yang ditengarai dengan beroperasinya Bank Muamalat Indonesia secara resmi pada tahun 1992 menunjukkan bahwa Indonesia telah 17 tahun bersinggungan dengan ekonomi Islam. Maka dari itu, baik sarana dan prasarana dalam bentuk apapun telah mulai menunjukkan kematangannya dalam mendukung kelancaran industri keuangan syariah.Beberapa diantara sarana dan prasarana tentunya adalah kesiapan SDM yang berbasis pendidikan formal akademik. Pendidikan formal akademik sendiri mempunyai beberapa konsentrasi dan jurusan yang berbeda dalam kaitannya dengan ekosistem ekonomi syariah. Salah satu di antaranya adalah studi dengan konsentrasi hukum ekonomi syariah (HES).

Dalam gambaran yang sangat umum, ekosistem ekonomi syariah selalu disebut kekurangan sumber daya manusia (SDM) yang kompeten. Dalam hal perbankan syariah yang mempunyai jurusan lebih banyak dari HES disebut bahwa hingga tahun 2015 dibutuhkan 45.000 orang yang belum semuanya terisi. ${ }^{1}$ Kondisi ketersediaan serta penyerapan SDM HES jauh lebih memprihatinkan dari pada SDM perbankan syariah ataupun ekonomi Islam.

Pada tahun 2007 pasca disahkannya Undang-Undang Nomor 18 Tahun 2003 tentang Advokat yang secara legal memberi ruang kepada lulusan fakultas syariah untuk bergabung menjadi advokat, hanya 7 berlatarbelakang syariah dari total 1137 calon advokat. ${ }^{2}$ Rilis data Asosiasi Pengacara Syariah Indonesia (APSI) pada tahun 2015 juga didapati bahwa jumlah anggotanya lembaga hukum maupun advokat terdaftar tidak lebih dari 6000 anggota. Padahal, Rosman telah menunjukkan urgensi keberadaan pengacara syariah yaitu untuk membantu menyelesaikan perkara-perkara pengadilan dalam koridor Islam yang sepatutnya. ${ }^{3}$

Dalam lingkup hakim pengadilan agama, disebutkan bahwa pada rangkaian tes SKD calon hakim agama pada seleksi PNS tahun 2017, hanya sekitar 400 orang yang lolos. Padahal, jumlah kuota yang dibutuhkan adalah 616 peserta dengan ekspektasi peserta lolos SKD adalah 3 kali lipatnya atau 1.848 orang. ${ }^{4}$ Peluang sarjana syariah untuk menjadi hakim memang ada, akan tetapi tidak banyak yang menangkap peluang kerja hakim sebagai opsi profesi yang bisa digeluti setelah menyelesaikan studi S1 nya.

Kekurangan lulusan syariah untuk kemudian tidak berkecimpung dalam profesi hukum memang mempunyai faktor penyebab yang banyak. Zainuddin telah merangkumnya pada 2 faktor

\footnotetext{
${ }^{1}$ M Ardiansyah, I Qizam, and J Setyono, 'Konstruksi Kopetensi Profesional Sarjana Ekonomi Syariah Pada Lembaga Keuangan Syariah', INFERENSI: Jurnal Penelitian Sosial Keagamaan, 7.1 (2013), 99-122.

${ }^{2}$ M Zainuddin, 'Peluang Dan Tantangan Sarjana Syariah Dalam Menggeluti Profesi Advokat Pasca Undang-Undang Nomor 18 Tahun 2003: Studi Kasus Di Banda Aceh Dan Aceh Besar', Petita: Jurnal Kajian Ilmu Hukum Dan Syariah, 1.1 (2017), 117-33.

${ }^{3}$ E Rosman, 'Urgensi Pengacara Syari'ah Dalam Penegakan Hukum Di Indonesia (Studi Analisis Partisipatoris Sarjana Syari'ah Dimasa Datang)', ALHURRIYAH: Jurnal Hukum Islam (ALHURRIYAH JOURNAL OF ISLAMIC $L A W), 16.1$ (2018), 79-94.

${ }^{4}$ I. R. S Turnip and A Hayati, Akseptabilitas Sarjana Hukum Islam Pada Seleksi Calon Hakim Peradilan Agama Di Mahkamah Agung RI Tahun 2017 (Bandung: Mujahid Press, 2019).
} 
utama, yaitu internal dan eksternal. ${ }^{5}$ Dari kedua faktor besar ini, elemen utama yang perlu menjadi sorotan lembaga penyedia pendidikan adalah kurikulum yang kurang mendukung alumni syariah untuk mampu terjun dalam profesi hukum. Banyak aspek keilmuan dalam bidang hukum yang seharusnya menjadi dasar dan tumpuan seseorang yang ingin berkecimpung dalam profesi hukum tidak terpenuhi.

Problematika kurikulum memang menjadi perbincangan di berbagai belahan negara. Kurikulum harus diperbaharui dan selalu disesuaikan dengan kondisi sosial serta kebutuhan industri saat ini. ${ }^{6}$ Meskipun pada hakikatnya keilmuan dipelajari untuk diamalkan dalam kehidupan personal sehari-sehari, tetapi dampak lain dari ketidaksinambungan antara kurikulum dan kebutuhan lapangan tentu menimbulkan banyaknya lulusan universitas tidak terserap dalam bursa tenaga kerja. Ketenagakerjaan memang mempunyai kebutuhan yang berubah-ubah pada tempat dan waktu. ${ }^{7}$ Di sisi lain, seorang lulusan perguruan tinggi biasanya tidak langsung siap dengan lingkungan pekerjaan dikarenakan mereka tidak mempunyai kemampuan kerja yang mumpuni. ${ }^{8}$ Maka dari itu, para peneliti seperti Ayoubi, dkk mengatakan bahwa merupakan tanggung jawab universitas untuk memastikan bahwa mahasiswa memiliki kemampuan cukup untuk dapat diserap dalam ketenagakerjaan. ${ }^{9}$

Dalam pengembangan kurikulum, Guimon dalam pemaparannya pada laporan kolaborasi antara OECD dan World Bank menyatakan bahwa keterlibatan industri mempunyai peran penting. ${ }^{10}$ Keterhubungan antara Industri dan Universitas yang salah satunya adalah pembuatan kurikulum dengan melibatkan industri memang secara empiris dapat membantu lulusan universitas dalam mendapatkan pekerjaan yang sesuai dengan bidang yang dipelajari. ${ }^{11}$

Konstruksi kurikulum untuk program studi HES menjadi sangat urgen mengingat beberapa paparan di atas terkait minimnya jumlah praktisi hukum ekonomi Islam yang terjun membantu menyokong ekosistem ekonomi Islam Indonesia. Terlebih lagi setelah diubahnya secara masif nomenklatur program studi serta gelar sarjana lulusannya, yang dulunya S.H.I atau S.Sy menjadi S.H. saja seperti program studi hukum umum lainnya. ${ }^{12}$ Jika hanya panduan yang dikeluarkan oleh

5Zainuddin, "Peluang Dan Tantangan Sarjana Syariah Dalam Menggeluti Profesi Advokat Pasca Undang-Undang Nomor 18 Tahun 2003: Studi Kasus Di Banda Aceh Dan Aceh Besar."

${ }^{6}$ B. S. Tessema and S. B. Abejehu, 'University-Industry Collaboration in Curriculum Development: Analysis of Banking and Finance Graduates' Attributes from Educators and Industries Perspective', Education Journal, 6.2 (2017), 87-93.

${ }^{7}$ R. W. McQuaid and C Lindsay, 'The Concept of Employability', Urban Studies, 42.2 (2005), 197-219.

${ }^{8} \mathrm{M}$ Abas-Mastura, O. A. Imam, and S Osman, 'Employability Skills and Task Performance of Employees in Government Sector', International Journal of Humanities and Social Science, 3.4 (2013), 150-62.

${ }^{9}$ R. M. Ayoubi, K Alzarif, and B Khalifa, 'The Employability Skills of Business Graduates in Syria: Do Policymakers and Employers Speak the Same Language?', Education+ Training, 59.1 (2017), 61-75.

${ }^{10} \mathrm{~J}$ Guimon, 'Promoting University-Industry Collaboration in Developing Countries', World Bank, 3 (2013), 12-48.

${ }^{11} \mathrm{E}$ Ishengoma and T. I. Vaaland, 'Can University-Industry Linkages Stimulate Student Employability?', Education+ Training, 58.1 (2016), 18-44.

${ }^{12}$ M. N Yasin, 'Politik Hukum Pemberlakuan Gelar" Sarjana Hukum" Untuk Alumni Jurusan Hukum Bisnis Syariah', Jurisdictie: Jurnal Hukum Dan Syariah, 7.2 (2016), 168-89. 
Fauzul Hanif Noor Athief, Azhar Alam, Nurul Latifatul Inayati

Kemenag, maka tentu perlu ada tambahan keilmuan yang diperlukan anak didik di atas standar yang telah ditetapkan.

Dalam panduan yang dikeluarkan oleh Direktorat Pendidikan Tinggi Keagamaan Islam Dirjen Pendidikan Islam Kemenag tahun 2018, disebutkan ada 3 profil lulusan utama dari program studi Hukum Ekonomi Syariah: praktisi hukum Islam, penghulu dan asisten peneliti. Adapun berdasarkan observasi penulis, biasanya ada beberapa profil lulusan yang ditambahkan di atas standar oleh program studi HES dari berbagai universitas. Di antaranya adalah: praktisi lembaga keuangan syariah dan praktisi hukum Islam dalam arti yang lebih holistik (hakim agama, pengacara, penghulu, penyuluh).

Penelitian ini secara spesifik akan mencoba mengelaborasi kebutuhan kurikulum program studi sebagaimana dibutuhkan oleh industri dan masyarakat (stakeholder) dengan mengacu pada SKL dan CPL Kemenag. Maka masalah yang ingin dipecahkan adalah apa saja mata kuliah yang relevan dan butuh diajarkan oleh program studi Hukum Ekonomi Syariah dengan profil lulusan sebagaimana disebutkan di atas. Selain itu, tingkat priortias mata kuliah juga akan dikaji untuk menentukan bobot yang diperlukan dalam pengajaran. Kedua rumusan masalah tersebut akan bisa dijawab menggunakan metode Analytic Network Process (ANP).

Tentunya diharapkan bahwa hasil penelitian ini bisa dijadikan rujukan oleh kampuskampus yang menyelenggarakan program studi dalam hal pembuatan kurikulum. Meskipun setiap kampus memiliki corak dan kekuatan SDM yang berbeda, setidaknya dengan adanya hasil kajian ini bisa menemukan sebuah standar yang disepakati praktisi sehingga bisa diimplementasikan oleh pihak kampus manapun.

\section{B. Kajian Literatur}

Penyusunan ulang kurikulum untuk menyesuaikan dengan kondisi masyarakat serta kebutuhan industri telah dilakukan pada berbagai bidang keilmuan di berbagai negara. Di Thailand, ada setidaknya 4 bidang keilmuan yang telah mempunyai interaksi baik antara Universitas dan industri. 2 di antaranya yaitu sektor pertanian dan teknik telah dikembangkan kurikulum yang berkaitan langsung dengan kebutuhan industri.13 Di China, Handong Global University telah membuat kolaborasi yang sangat bagus dengan LG Electronics melalui penyempurnaan kurikulum bersama. ${ }^{14}$ Studi yang dilakukan oleh Pilgrim juga telah mendokumentasikan bahwa keterlibatan industri dalam penyusunan kurikulum di bidang teknik informatika di Australia telah membuahkan kesuksesan. 15

\footnotetext{
${ }^{13} \mathrm{P}$ Brimble and R. F. Doner, 'University-Industry Linkages and Economic Development: The Case of Thailand', World Development, 35.6 (2007), 1021-36.

${ }^{14} \mathrm{D}$. H. Lee and others, 'Development of Partnership between Industry and University via Customized FieldOriented Curriculum', in 2005 IEEE International Conference on Microelectronic Systems Education (MSE'05) (IEEE, 2005), pp. 81-82.

${ }^{15} \mathrm{C}$. J Pilgrim, 'Industry Involvement in ICT Curriculum: A Comparative Survey.', in Proceedings of the 2013 International Conference on Software Engineering (IEEE Press, 2013), pp. 1148-53.
} 
Dalam kajian yang dilakukan oleh Lee dan Win juga ditemukan bahwa transfer teknologi antara Pusat Penelitian Universitas dan Industri di Singapura juga telah dilakukan. ${ }^{16}$ Kerjasama riset dan pembangungan ( $R$ \& D) adalah bentuk transfer yang paling signifikan hasilnya. Meski begitu, di dalam penelitian mereka juga disebutkan bahwa pembentukan kurikulum bersama atas dasar proyek tertentu juga dilakukan oleh pusat-pusat penelitian tersebut.

Pada riset lain, aspek yang dikembangkan memang bukan hanya dalam bentuk kurikulum tetapi juga terkait soft skill yang perlu dikembangkan agar para almuni universitas mempunyai kemampuan dasar untuk bekerja di industri. Salah satunya adalah penelitian oleh Laguador dan Ramos yang mencoba mencari tau bagaimana ekspektasi industri pada para lulusan. Hasilnya menyatakan bahwa memang kemampuan teknis pekerjaan, penelitian, komunikasi, komputer serta kepemimpinan, sikap dalam pekerjaan serta loyalitas penting dan seharusnya diintegrasikan dalam sebuah kurikulum. ${ }^{17}$

Pengembangan kurikulum dengan keikutsertaan industri bukan hanya dilakukan pada bidang teknik saja. Bidang ekonomi dan bisnis juga telah disorot dan bahkan telah dikembangkan kurikulumnya dengan melibatkan pihak industri. Dalam tatanan konsep, telah banyak kajian yang meneliti tentang aspek apa yang seharusnya dimasukkan dalam kurikulum. Walker dan Black misalkan telah menawarkan pendekatan proses yang bisa dikembangkan untuk mengeliminasi redundansi dalam penyusunan kurikulum untuk bidang ekonomi dan bisnis. ${ }^{18}$ Penelitian empiris yang membuahkan rekomendasi untuk penambahan kurikulum di bidang ekonomi bisnis juga telah dilakukan oleh Daud dkk serta Abbasi dkk. Kajian pertama menyatakan bahwa industri memberi set bobot berbeda pada berbagai macam indikator kemampuan pekerja, ${ }^{19}$ sedangkan artikel kedua mengidentifikasi soft skill yang dibutuhkan oleh para pemberi kerja. ${ }^{20}$ Keduanya menyarankan agar kurikulum dikembangkan berdasarkan kebutuhan ini.

Hasil empiris juga telah menyatakan bahwa pengembangan kurikulum memang membuahkan hasil. North-West University di Afrika Selatan misalnya telah mengembangkan kurikulum dengan menambahkan Business Mathematics and Informatics. Hasil dari pengembangan kurikulum tersebut adalah mayoritas lulusan diterima bekerja pada sektor keuangan. ${ }^{21}$ Tessema dan Abejehu juga menyatakan bahwa kolaborasi universitas-industri dalam

16J Lee and H. N Win, 'Technology Transfer between University Research Centers and Industry in Singapore', Technovation, 24.5 (2004), 433-42.

${ }^{17}$ J. M. Laguador and L. R. Ramos, 'Industry-Partners' Preferences for Graduates: Input on Curriculum Development', Journal of Education and Literature, 1.1 (2014), 1-8.

${ }^{18} \mathrm{~K}$. B. Walker and E. L. Black, 'Reengineering the Undergraduate Business Core Curriculum: Aligning Business Schools with Business for Improved Performance', Business Process Management Journal, 6.3 (2000), 194-213.

${ }^{19} \mathrm{~S}$ Daud and others, '). Enhancing University Business Curriculum Using an Importance-Performance Approach: A Case Study of the Business Management Faculty of a University in Malaysia.', International Journal of Educational Management, 25.6 (2011), 545-69.

${ }^{20}$ F. K. Abbasi, A Ali, and N Bibi, 'Analysis of Skill Gap for Business Graduates: Managerial Perspective from Banking Industry', Education+ Training, 60.4 (2018), 354-67.

${ }^{21} \mathrm{~F}$. K. Boersma, C. J. Reinecke, and M. Gibbons, 'Organizing the University-Industry Relationship: A Case Study of Research Policy and Curriculum Restructuring at the North-West University in South Africa', Tertiary Education and Management, 14.3 (2008), 209-26 <https://doi.org/10.1080/13583880802228216>. 
Fauzul Hanif Noor Athief, Azhar Alam, Nurul Latifatul Inayati

pengembangan kurikulum telah sukses membuat industri perbankan dan keuangan di Ethiopia berpendapat bahwa para pekerja telah mendapat pengetahuan dan kemampuan yang cukup. ${ }^{22}$

Jika pengembangan kurikulum untuk ekonomi dan bisnis konvensional telah mendapat perhatian yang besar, maka dalam hal ekosistem ekonomi Islam beserta seluruh bidang ilmu di dalamnya dengan spesifik area di Indonesia sudah mulai memunculkan perhatian tersebut. Hal itu bisa dilihat dari sejumlah kajian yang dihasilkan oleh para peneliti.

Di antara kajian yang paling banyak dirujuk adalah penelitian Amalia dan Al Arif. Penelitian ini secara spesifik mencoba menganalisa tentang peran PTU (Perguruan Tinggi Umum) dan PTAI (Perguruan Tinggi Agama Islam) dalam menyiapkan SDM yang bisa mengakomodasi kebutuhan industri. Dengan menggunakan analisa jalur (path analysis), penelitian ini mendapati bahwa antara persepsi akademisi akan kurikulum, model pembelajaran dan persepsi praktisi terkait kompetensi SDM memang saling berkaitan. Kemudian, analisa isi (content analysis) terhadap kurikulum pada penelitian ini menunjukkan bahwa kompetensi yang dihasilkan antar program studi akan berbeda tergantung kepada sistem pembelajaran dan kurikulum. ${ }^{23}$

Pada tahun yang sama, kajian yang cukup mirip juga dilakukan oleh Ardiansyah dkk. Tiga variabel dijadikan bahan penelitian, yaitu persepsi perguruan tinggi, persepsi mahasiswa program studi ekonomi Islam dan persepsi industri lembaga keuangan syariah. Metode analisa yang digunakan juga sama dengan Amalia dan Al Arif yaitu menggunakan analisa jalur. Yang menarik adalah hasil kajian yang menunjukkan bahwa ada kesenjangan antara kompetensi yang disusun oleh pihak perguruan tinggi dan kebutuhan industri. Adapun persepsi perguruan tinggi terhadap persepsi mahasiswa terdapat hubungan positif. ${ }^{24}$

Dua penelitian di atas menyasar kepada pembuktian empiris pentingnya kurikulum berbasis kebutuhan industri. Sayangnya, keduanya tidak menyentuh terkait apa saja yang perlu dimasukkan ke dalam kurikulum, atau lebih spesifik lagi mata kuliah apa yang butuh diajarkan oleh pihak kampus. Ada juga penelitian Sari yang kemudian membahas apa saja aspek yang butuh dielaborasikan di dalam kurikulum. Meskipun begitu, penelitiannya terkesan sangat normatif menjelaskan tentang langkah-langkah penyusunan kurikulum, prinsip pengembangan kurikulum serta landasan normatif tentang hal-hal yang diperlukan dalam mendesain ulang suatu kurikulum. ${ }^{25}$ Penelitian serupa dilakukan oleh Suryanti dkk yang melakukan wawancara terhadap sejumlah praktisi industri. Hasil yang didapatkan oleh penelitian ini adalah capaian pembalajaran

\footnotetext{
${ }^{22}$ Tessema and Abejehu.

${ }^{23}$ E Amalia and M. N. R. Al Arif, 'Kesesuaian Pembelajaran Ekonomi Islam Di Perguruan Tinggi Dengan Kebutuhan Sdm Pada Industri Keuangan Syariah Di Indonesia', INFERENSI: Jurnal Penelitian Sosial Keagamaan, 7.1 (2013), 123-42.

${ }^{24}$ Ardiansyah, Qizam, and Setyono.

${ }^{25} \mathrm{~N}$ Sari, 'Re-Design Kurikulum Ekonomi Syariah Perguruan Tinggi Agama Islam', Jurnal Ilmiah Peuradeun, 2.3 (2014), 135-54
} 
pada sikap, tata nilai, pengetahuan serta keterampilan dan juga terkait kompetensi yang dibutuhkan oleh bank syariah. ${ }^{26}$

Sebagaimana terlihat bahwa dari seluruh kajian di atas tidak ada satupun yang menyinggung tentang mata kuliah apa yang secara spesifik dibutuhkan oleh masyarakat maupun industri. Kebanyakan kajian menyinggung hal yang lebih umum seperti persepsi antara akademisi dan industri serta landasan normatif dalam pembuatan kurikulum secara general. Selain itu, topik yang dibahas juga lebih menjurus kepada ekonomi dan keuangan Islam, bukan dalam hukum ekonomi syariah. Dalam lingkup ekonomi dan keuangan Islam sebenarnya sudah ada penelitian yang spesifik membahas mata kuliah, yaitu yang dilakukan oleh Belabes dkk di Saudi ${ }^{27}$ dan Akhtyamova dkk (2014) di Rusia. ${ }^{28}$

Berdasarkan urgensi yang telah dipaparkan di atas serta ketiadaan literatur yang dapat membantu menyelesaikan rumusan masalah, maka kajian kami ini akan menambah khazanah serta memperkaya literatur terkait pengembangan mata kuliah ajar yang disusun berdasarkan kolaborasi industri dan universitas.

\section{Metode}

Penelitian ini merupakan eksploratori terhadap masalah mata kuliah pembelajaran. Pendekatan campuran antara kualitatif dan kuantitatif dilakukan untuk menangkap nilai dan pandangan dari para praktisi. Penelitian ini menggunakan data primer yang didapat dari wawancara bersama para pakar dan praktisi. Wawancara ini ditujukan untuk mendapat gambaran umum terkait topik yang diangkat pada penelitian ini. Pada pertemuan kedua dilanjutkan dengan pengisian kuesioner untuk mendapatkan data dan respon atas kerangka masalah yang didapatkan berdasarkan wawancara pertama.

Adapun pemilihan sampel dilakukan dengan cara purposive sampling yang memang lebih cocok untuk fenomena sosial. ${ }^{29}$ Responden yang dipilih adalah para praktisi dalam bidang hukum Islam, lembaga keuangan Islam serta lembaga ekonomi Islam profesional. Hal ini dilakukan agar data yang didapatkan bisa merepresentasikan kebutuhan industri dan masyarakat. Responden yang menjadi narasumber adalah 3 orang hakim, 4 orang direktur BMT serta 3 orang advokat. Dengan demikian terdapat keseimbangan opini antar profesi.

\footnotetext{
${ }^{26}$ S. Suryanti, A Ibrahim, and A Ayumiati, 'Analisis Kompetensi Kurikulum Prodi Perbankan Syariah Uin Ar-Raniry Banda Aceh Dan Kesesuaiannya Dengan Kebutuhan Bank Syariah.', JIHBIZ: Global Journal of Islamic Banking and Finance., 1.1 (2019).

${ }^{27}$ A Belabes, A Belouafi, and M Daoudi, 'Designing Islamic Finance Programmes in a Competitive Educational Space: The Islamic Economics Institute Experiment', Procedia-Social and Behavioral Sciences, 2015, 639-43.

${ }^{28} \mathrm{~N}$ Akhtyamova, M Panasyuk, and R Azitov, "The Distinctive Features of Teaching of Islamic Economics: Philosophy, Principles and Practice', Procedia - Social and Behavioral Sciences, 191 (2015), 2334-38.

${ }^{29}$ M. N. Marshall, 'Sampling for Qualitative Research', Family Practice, 13.6 (1996), 522-26. Lihat juga M. L. Small, 'How Many Cases Do I Need? On Science And The Logic Of Case Selection In Field-Based Research', Ethnography, 10.1 (2009), 5-38.
} 
Fauzul Hanif Noor Athief, Azhar Alam, Nurul Latifatul Inayati

Untuk analisa data, penelitian ini menggunakan ANP (Analytic Network Process) karena cocok digunakan untuk problematika terkait pembuatan keputusan. Saaty mendifiniskan ANP sebagai alat yang bisa digunakan untuk mengukur rasio prioritas yang merefleksikan pengukuran relatif dari elemen yang saling berhubungan. ${ }^{30}$ Azis mendeskripsikan ANP sebagai teori matematis yang memungkinkan seseorang untuk berurusan dengan variabel dependen beserta feedback-nya yang kemudian dimunculkan dalam bentuk rasio. ${ }^{31}$ ANP sendiri memiliki 4 aksioma penting: Resiprokal, homogenitas, prioritas dan kondisi yang tidak berkaitan. ${ }^{32}$

Tahapan yang dilakukan dalam penelitian ini adalah sebagai berikut: ${ }^{33}$ Pertama: Konstruksi model. Hal ini dilakukan melalui pembacaan literatur yang ekstensif sehingga nantinya pertanyaan wawancara yang dilakukan kepada para pakar dan praktisi bisa menggali data yang jauh lebih mendalam. Hasil dari pembacaan literatur itulah yang nantinya dibandingkan dengan hasil dari wawancara bersama para pakar.

Kedua: Kuantifikasi model. Tahap kuantifikasi model menggunakan pertanyaan kuesioner berupa pairwise comparison (pembandingan berpasangan) antara elemen di dalam cluster untuk mengetahui mana di antara keduanya yang lebih besar pengaruhnya serta seberapa besar perbedaannya. Perbandingan tersebut direpresentasikan melalui skala yang telah dikembangkan oleh Ascarya sebgaimana bisa dilihat pada tabel $1 .{ }^{34}$ Seluruh data yang didapatkan dari pertanyaan kuesioner kemudian dianalisa untuk menghasilkan output terkait skala prioritas.

Tabel 1. Perbandingan skala verbal dan skala numerik

\begin{tabular}{lc}
\hline Skala Verbal & Skala Numerik \\
\hline Amat sangat lebih besar pengaruhnya & 9 \\
Sangat lebih besar pengaruhnya & 8 \\
Lebih besar pengaruhnya & 7 \\
Sedikit lebih besar pengaruhnya & 6 \\
& 5 \\
Sama besar pengaruhnya & 4 \\
\end{tabular}

Ketiga: Analisa Hasil. Pada tahap ini tendensi dari jawaban seluruh responden dihitung menggunakan averages mean dan bukan geometric mean. Hal ini karena averages mean sudah cukup untuk merepresentasikan hasil. Tingkat kesepakatan antara responden selanjutnya diukur

\footnotetext{
${ }^{30}$ T. L. Saaty, Fundamentals of Decision Making (Pittsburgh: RWS Publication, 1994).

31I. J. Aziz, 'Analytic Network Process With Feedback Influence: A New Approach to Impact Study', in Analytic Network Process With Feedback Influence: A New Approach to Impact Study (University of Illinois at UrbanaChampaign, 2003).

${ }^{32}$ T. L. Saaty and L. G. Vargas, Decision Making with the Analytic Network Process: Economic, Political, Social and Technological Applications with Benefits, Opportunities, Costs and Risks (New York: Springer Science + Business Media, 2006).

${ }^{33}$ Ascarya and D Yumanita, Determinan Dan Persistensi Margin Perbankan Konvensional Dan Syariah Di Indonesia, 2010.

${ }^{34}$ Ascarya, Analytic Network Process (ANP): Pendekatan Baru Studi Kualitatif (Jakarta: Pusat Pendidikan dan Studi Kebanksentralan, Bank Indonesia., 2005).
} 
menggunakan Kendall's Coefficient of Concordance (W). Kendall's Coefficient memiliki nilai 0 sampai 1 dimana $\mathrm{W}=1$ berarti seluruh jawaban antar responden memiliki kesepakatan yang sempurna sedangkan $\mathrm{W}=0$ menunjukkan sama sekali tidak ada kesepakatan.

Penghitungan average mean dilakukan setelah mendapatkan normalized Eigenvalue dari hasil input data setiap responden dengan formula berikut:

$$
\bar{x}=\frac{x_{1}+x_{2}+x_{3}+\ldots x_{n}}{\mathrm{~N}}
$$

Perhitungan rater agreement yang menunjukkan tingkat kesepakatan antar responden menggunakan Kendall's Coefficient dilakukan dengan rumus berikut:

$$
W=\frac{12 \sum d_{i}^{2}}{\mathrm{~m}^{2} \mathrm{n}\left(\mathrm{n}^{2}-1\right)}
$$

Adapun alur penelitian dalam bentuk diagram adalah sebagaimana pada diagram 1.

Diagram 1. Tahapan penelitian

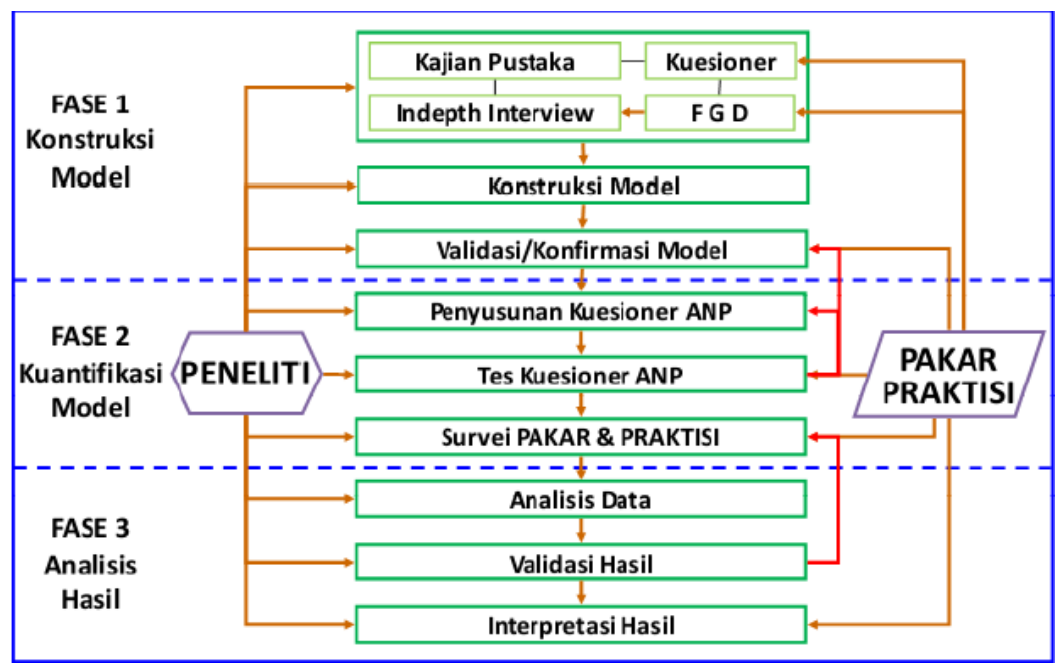

\section{Hasil dan Pembahasan}

Sebagai tahap pendahuluan sebelum melaksanakan wawancara dan olah data, dilakukan observasi terhadap kurikulum yang diterapkan pada berbagai universitas. Untuk menjaga kualitas penelitian, maka dilakukan proses seleksi terhadap literatur-literatur kurikulum tersebut. Penelitian ini mengambil hanya kurikulum dari kampus dengan program studi (prodi) Hukum Ekonomi Syariah berakreditasi A yang masih berlaku hingga penelitian dilakukan dengan jumlah 8 prodi. Dari penelusuran literatur tersebut, didapati rumpun-rumpun mata kuliah sebagai berikut:

- Fikih

- Ekonomi Islam

- Hukum

- Komplementari Hukum

- Bahasa

Dari 5 rumpun tersebut, masing-masing prodi memiliki variasi mata kuliahnya tersendiri. Sebagai tahap permulaan ANP, maka dilakukan pengelompokan lebih lanjut dari sebaran mata 
Fauzul Hanif Noor Athief, Azhar Alam, Nurul Latifatul Inayati

kuliah yang ada. Hasil pengelompokan ini kemudian dibawa kepada tahap berikutnya dari prosedur permulaan ANP, yaitu Focus Group Discussion (FGD) dengan para pakar. Pakar yang dipilih untuk FGD memiliki latar belakang yang berbeda yaitu praktisi hukum dan praktisi lembaga keuangan sehingga diskusi yang dihasilkan menjadi lebih komprehensif dari berbagai perspektif. Atas dasar FGD tersebut kemudian dirumuskan konstruksi model ANP yang menjadi framework (bingkai) dasar penelitian. Adapun framework penelitian ini bisa dilihat pada diagram 2.

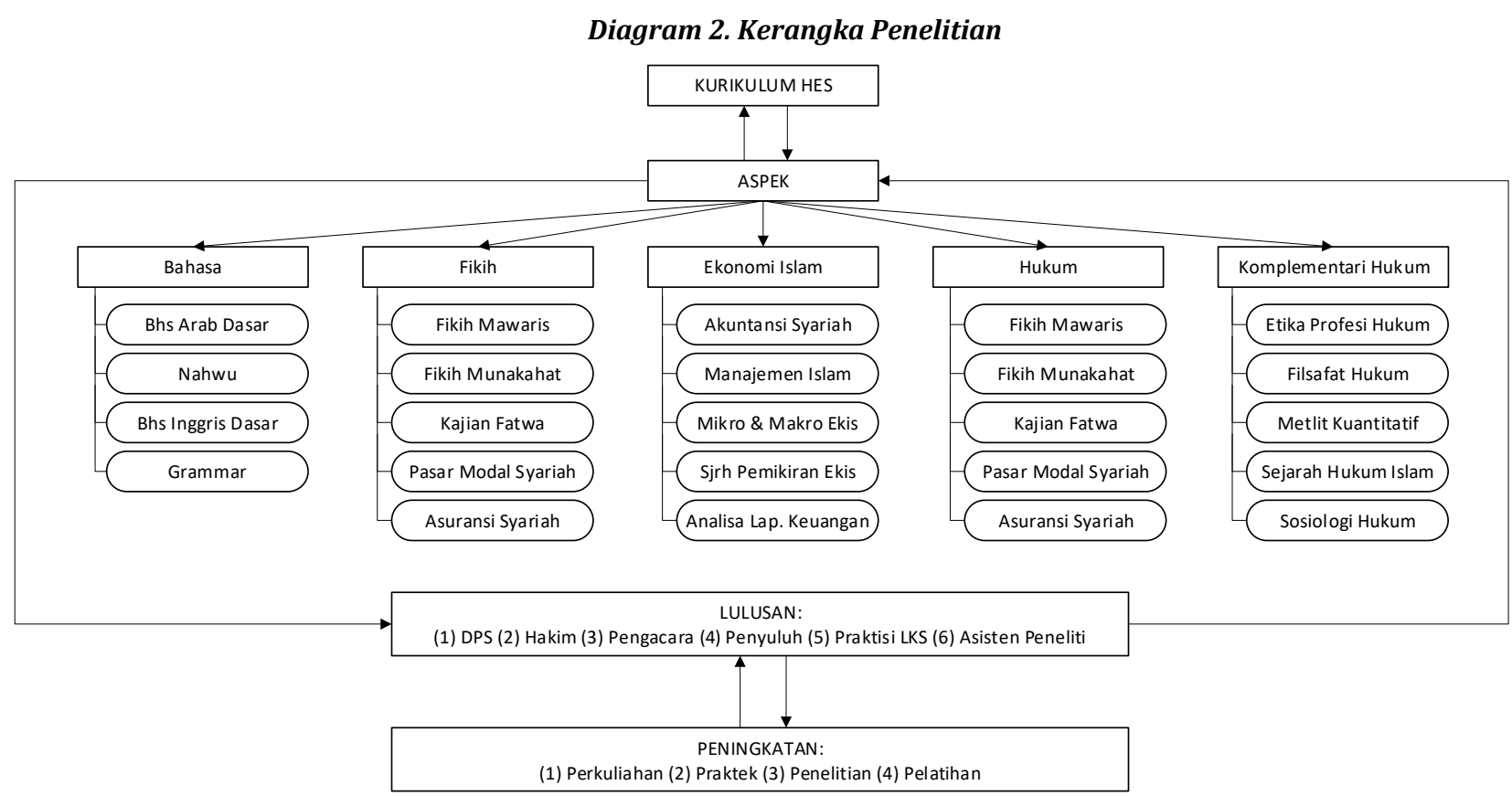

Variabel yang digunakan dalam penelitian ini khususnya pada kelompok aspek yang terpecah menjadi 5 sub-aspek memang memiliki elemen yang hanya sedikit dibanding jumlah mata kuliah pada umumnya. Hal ini dikarenakan dalam penelusuran literatur dan atas FGD bersama para pakar, didapati banyak mata kuliah yang memang selalu ada pada prodi Hukum Ekonomi Syariah di berbagai universitas. Menanyakan ulang urgensinya dibanding mata kuliah lain menjadi tidak relevan dikarenakan nilai kepentingannya menjadi sama. Misalnya saja untuk sub-aspek Fikih, hampir seluruh kampus didapati menyajikan Fikih Muamalah dasar dan lanjutan, Usul Fikih dasar dan lanjutan, Kaidah Fikih dasar dan lanjutan, zakat serta wakaf. Kemudian untuk sub-aspek Hukum, bisa didapati dengan mudah bahwa hampir seluruh kampus menyajikan Hukum Perdata, Hukum Acara Perdata, Pengantar Ilmu Hukum, Pengantar Tata Hukum Indonesia, Hukum Dagang, Hukum Perikatan serta beberapa variasi terkait mata kuliah tersebut. Kemudian juga pada subaspek Ekonomi Islam, selalu didapati hampir setiap kampus menawarkan mata kuliah Lembaga Keuangan Syariah beserta unsur-unsur di dalamnya yang tidak jarang menjadi mata kuliah terpisah.

Maka dari itu unsur yang dimasukkan menjadi variabel dan dijadikan poin pertanyaan kueisoner adalah mata kuliah yang dipakai oleh sebagian kampus, sedangkan kampus yang lain tidak. Hal ini berfungsi agar nanti para pakar praktisi memberikan pandangan mereka terkait 
kebutuhan pemegang kepentingan terhadap mata kuliah tersebut. Tingkat kepentingan menurut pakar itulah yang kemudian bisa dijadikan pertimbangan bagi kampus-kampus untuk memasukkanya dalam silabus mereka atau tidak. Adapun untuk mata kuliah yang hanya muncul pada satu atau dua kampus dan dinyatakan dalam FGD untuk dihapus dari model maka tidak dimunculkan seperti Balaghah, Ilmu Falak, Hukum Kenotariatan, Hukum Lingkungan, Fikih Lingkungan, Administrasi Peradilan Agama, Institusi Hisbah dan berbagai mata kuliah lain.

Responden yang menjadi narasumber pada penelitian ini berjumlah 10 yang berasal dari berbagai latar belakang berbeda. 3 responden adalah hakim dengan salah satu di antara mereka adalah ketua pengadilan. 3 responden lain adalah advokat senior, Ketua Umum APSI, serta mediator yang juga pengurus DPP APSI. Selanjutnya, 4 responden lain adalah para eksekutif manager dari berbagai BMT. Berdasarkan wawancara kepada para responden, didapatkan hasilhasil berikut. Hasil yang dipaparkan adalah setelah penghitungan matrik jawaban dengan limiting model dan dinormalisasikan untuk mendapat nilai bulat 1. Adapun hasil-hasilnya adalah sebagai berikut.

1. Aspek Umum

Tabel 2. Hasil hitung pada kelompok Aspek Umum

\begin{tabular}{lcc}
\hline Elemen & Nilai & Ranking \\
\hline Bahasa & 0.146 & 5 \\
Ekonomi Islam & 0.227 & 2 \\
Fikih & 0.200 & 3 \\
Hukum & 0.243 & 1 \\
Komplementari Hukum & 0.182 & 4 \\
\hline Nilai Kendalls' coeifficient (W) untuk rater agreement adalah 0.270
\end{tabular}

Sebagai tahap awal dalam pendalaman opini para narasumber, maka survey awal yang dilakukan adalah terkait pendapat para pakar ini terhadap bidang mata kuliah apa saja yang relevan dan butuh dipelajari bagi mahasiswa HES. Dengan rater agreement sebesar 0.270, para pakar sepakat bahwa Hukum umum menduduki peringkat pertama. Pada peringkat kedua dan ketiga adalah Ekonomi Islam dan Fikih secara berurutan. Tiga bidang ini memang merupakan kompetensi utama bagi pembelajar HES. Akan tetapi yang menarik dicatat adalah bahwasanya penguasaan terhadap Fikih justru hanya mendapat peringkat ke-3. Adapun untuk aspek Bahasa semuanya sepakat materinya masih tidak perlu mendapat porsi yang besar. Berdasarkan wawancara, memang seluruh responden berbicara cukup panjang untuk menekankan pentingnya 3 aspek tersebut. Pergantian gelar sarjana dari S.H.I. menjadi S.H. juga disambut sangat baik oleh para hakim dan pengacara. Adapun responden dari pihak lembaga keuangan menyatakan bahwa prodi ini tetap perlu menyentuh aspek ekonomi syariah. 
2. Kompetensi Bahasa

Tabel 3. Hasil hitung pada kelompok Kompetensi Bahasa

\begin{tabular}{lcc}
\hline Elemen & Nilai & Ranking \\
\hline Arab Dasar & 0.347 & 1 \\
Grammar & 0.162 & 4 \\
Inggris Dasar & 0.256 & 2 \\
Nahwu & 0.233 & 3
\end{tabular}

Catatan: Nilai Kendalls' coeifficient (W) untuk rater agreement adalah0.185

Memasuki kepada spesifik aspek Bahasa, peneliti menggunakan 4 indikator yang hasil penghitungan prioritasnya bisa dilihat pada Tabel 3. Peneliti tidak membuat klasifikasi berdasarkan penguasaan Bahasa secara aktif maupun pasif dikarenakan dalam praktik profesi, Bahasa aktif memang tidak terlalu dibutuhkan. Hasil dari Tabel 3 tidak terlalu mengejutkan. Bahasa Arab Dasar dan Bahasa Inggris Dasar yang berupa pemahaman kosa kata, susunan atau rangkaian atas sejumlah kata menduduki peringkat pertama dan kedua secara berurutan. Bahkan Bahasa Arab Dasar mendapat prioritas hingga 35\% dengan Bahasa Inggris Dasar hanya 25\%. Adapun ilmu linguistik untuk memahami detail alasan mengapa suatu kata disusun dengan rangkaian tertentu sebagaiman dipelajari pada Nahwu maupun Grammar tidak menjadi prioritas. Hal ini karena memang pada praktiknya banyak yang tidak memahami mendalam baik itu Nahwu maupun Grammar tetapi tetap dapat memahami substansi penting dari suatu teks.

Dari sini dapat dipahami bahwa kampus-kampus seyogyanya menekankan pemberian keilmuan dasar Bahasa Arab maupun Inggris. Pendalaman hingga Nahwu maupun Grammar adalah komplemen yang jika memang kampus tersebut telah membuat standar Bahasa tertentu bagi alumninya, maka pendalaman tersebut menjadi relevan.

Informasi menarik tambahan berdasarkan hasil wawancara adalah adanya responden dari Pengadilan Agama Boyolali yang menyatakan bahwa bahasa Belanda sebetulnya juga dibutuhkan. Hal ini mengingat bahwa rujukan hukum Indonesia adalah Belanda. Namun andai dia dimasukkan dalam variabel penelitian ini, hakim tersebut menyatakan bahwa butuhnya hanya sebatas kompetensi pasif berupa pengetahuan istilah-istilah hukum.

3. Kompetensi Ekonomi Islam

\begin{tabular}{lcc}
\multicolumn{3}{l}{ Tabel 4. Hasil hitung pada kelompok Kompetensi Ekonomi Islam } \\
\hline Elemen & Nilai & Ranking \\
\hline Akuntansi Syariah & 0.210 & 2 \\
Analisa Lap. Keuangan & 0.232 & 1 \\
Makro \& Mikro Ekis & 0.202 & 3 \\
Manajemen Pemasaran Islam & 0.184 & 4 \\
Sejarah Ekonomi Islam & 0.170 & 5
\end{tabular}

Catatan: Nilai Kendalls' coeifficient (W) untuk rater agreement adalah 0.074 
Sebagaimana telah disebutkan bahwa untuk aspek Kompetensi Ekonomi Islam ada beberapa mata kuliah yang telah disetujui urgensinya yang tergabung dalam payung besar pelajaran Lembaga Keuangan Islam serta pendahuluan terhadap Ekonomi Islam. Adapun Makro dan Mikro Ekonomi Islam masih dimasukkan ke dalam pertanyaan survey dikarenakan sebagian kampus mencukupinya dengan materi pendahuluan saja.

Hasil yang didapatkan sangat menarik. Para pakar setuju dengan nilai prioritas $23 \%$ bahwa mata kuliah Analisa Laporan Keuangan seharusnya ditawarkan kepada mahasiswa. Beberapa pakar menekankan bahwa profesi baik sebagai Dewan Pengawas Syariah maupun Ahli Hukum seharusnya memiliki kemampuan untuk menelaah laporan keuangan. Bagi DPS, telaah laporan keuangan adalah untuk mengetahui kecacatan terkait hukum Islam. Bagi Ahli Hukum, kemampuan tersebut membantu untuk mengidentifikasi fraud yang dilakukan oleh LKS. Menyusul pada prioritas kedua adalah Akuntansi Syariah yang pada hakikatnya adalah ilmu dasar sebelum mampu melakukan analisa laporan keuangan.

Hasil penelitian juga menunjukkan bahwa Makro dan Mikro Ekonomi Islam tidak terlalu menjadi prioritas karena sudah diwakili dengan Pengantar Ekonomi Islam. Manajemen Pemasaran Islam Serta Sejarah Ekonomi Islam tidak terlalu penting bagi seorang sarjana HES yang bergelar S.H. atau seorang ahli hukum.

Temuan tambahan dari hasil wawancara adalah urgensi pengetahuan SDM lulusan HES terkait analisa laporan keuangan. Stakeholder dari para direktur BMT menyatakan bahwa jika lulusan HES nantinya menjadi Dewan Pengawas Syariah (DPS) di sebuah lembaga keuangan, maka ketidakmampuan melakukan analisa laporan keuangan membuat posisinya tidak terlalu bermakna. Ia hanya menerima analisa dan presentasi dari pihak lembaga keuangan tanpa mampu melakukan analisa secara mandiri dan jauh lebih independen. Para direktur BMT mengatakan mayoritas DPS tidak mempunyai kompetensi ini sehingga perlu dimasukkan dalam kurikulum.

4. Kompetensi Fikih

Tabel 5. Hasil hitung pada kelompok Kompetensi Fikih

\begin{tabular}{lcc}
\hline Elemen & Nilai & Ranking \\
\hline Asuransi Syariah & 0.228 & 3 \\
Fikih Mawaris & 0.172 & 4 \\
Fikih Munakahat & 0.120 & 5 \\
Kajian Fatwa & 0.242 & 1 \\
Pasar Modal Syariah & 0.235 & 2 \\
\hline
\end{tabular}

Catatan: Nilai Kendalls' coeifficient (W) untuk rater agreement adalah 0.2195

Selanjutnya adalah Kompetensi Fikih. Pada aspek ini seluruh kajian terkait fikih muamalah dasar dan lanjutan, usul fikih dasar dan lanjutan, kaidah fikih dasar dan lanjutan, zakat serta wakaf adalah mata kuliah yang selalu ditemukan pada berbagai kampus. Adapun untuk mata kuliah selain itu, hasil penelitian ini menunjukkan bahwa kajian fatwa menduduki prioritas tertinggi yaitu 0.242 
Fauzul Hanif Noor Athief, Azhar Alam, Nurul Latifatul Inayati

atau 24\%. Para pakar menyatakan bahwa dasar hukum ketika sengketa adalah fatwa MUI. Maka dari itu selain pemahaman fikih, usul fikih dan kaidah fikih, penerapan keilmuan terhadap fatwa juga menjadi sangat penting.

Pada peringkat prioritas kedua dan ketiga adalah Pasar Modal Syariah dan Asuransi Syariah yang masing-masing hanya terpaut $1 \%$ dari prioritas sebelumnya. Pasar Modal Syariah dan Asuransi Syariah memang bentuk lanjutan dari teori-teori fikih dalam bentuk kontrak-kontrak yang sangat modern. Mata kuliah fikih dan ushul fikih tentu sesekali mengambil contoh dari praktik pada pasar modal maupun industri asuransi. Bagaimanapun juga, konsentrasi lebih terhadap dua kajian ini dianggap penting oleh para pakar dikarenakan kompleksitas praktik akad pada dua kajian ini.

Fikih Mawaris yang mempunyai persinggungan antara Hukum Ekonomi Syariah dan Hukum Keluarga hanya mendapat prioritas 0.172. Adapun Fikih Munakahat yang memang ranah utama dari Hukum Keluarga hanya mendapat prioritas 0.120. Artinya prodi Hukum Ekonomi Syariah jika mencantumkan mata kuliah Fikih Munakahat, selain harus tercantum pada profil lulusan, maka harus mengetahui bahwa para stakeholder merasa mata kuliah ini tidak relevan.

Temuan tambahan dari hasil wawancara menunjukkan bahwa urgensi kompetensi kajian fatwa adalah 2, yaitu untuk SDM yang bergerak di ranah hukum serta SDM yang berprofesi sebagai DPS. Para responden hakim dan pengacara menyatakan bahwa dikarenakan landasan utama pengambilan hukum adalah fatwa, maka kajian fatwa harus dimunculkan pada kurikulum. Adapun para direktur BMT menyatakan bahwa seluruh operasional BMT harus tunduk kepada fatwa MUI. Hal ini menjadikan kompetensi kajian fatwa tidak boleh dilewatkan.

\section{Kompetensi Hukum}

Dalam tinjauan survey awal terkait aspek umum, Kompetensi Hukum mendapatkan prioritas utama. Adapun pada bagian ini, yang dimasukkan dalam survey terkait Kompetensi Hukum adalah bidang pelajaran yang terkadang dipakai di satu kampus, tetapi tidak digunakan di kampus lain. Adapun mata kuliah yang tidak dimasukkan dalam survey tahap ini adalah Hukum Perdata, Hukum Acara Perdata, Pengantar Ilmu Hukum, Pengantar Tata Hukum Indonesia, Hukum Dagang, Hukum Perikatan serta beberapa variasi terkait mata kuliah tersebut.

\begin{tabular}{ccc}
\multicolumn{4}{c}{ Tabel 6. Hasil hitung pada kelompok Kompetensi Hukum } \\
\cline { 2 - 3 } Elemen & Nilai & Ranking \\
\hline Arbitrase & 0.234 & 1 \\
Hkm Perlindungan Kons & 0.199 & 4 \\
Hukum Jaminan & 0.212 & 2 \\
Hukum Pidana & 0.147 & 5 \\
Catatan: & Nilai Kendalls' coeifficient (W) untuk rater agreement adalah0.077
\end{tabular}


Hasil riset menunjukkan temuan menarik. Arbitrase memiliki peringkat prioritas utama dengan nilai 0.234 . Dalam wawancara dengan para pakar, memang banyak yang menyebutkan bahwa perkara-perkara perdata di Pengadilan Agama seharusnya bisa diselesaikan terlebih dahulu melalui musyawarah dalam forum arbitrase. Hal ini mengingat prinsip ajaran Islam yang mendahulukan musyawarah serta sifat muslim sejati yang tidak pernah mengingkari janji. Masih berkaitan dengan perkara perdata, hukum jaminan menempati prioritas selanjutnya dengan nilai 0.212. Hal ini mengingat bahwa perkara fasilitas pembiayaan hampir tidak pernah terlepas dari jaminan yang diberikan oleh pelanggan terhadap sebuah lembaga keuangan syariah. Prioritas selanjutnya adalah legal drafting. Materi ini ditekankan oleh beberapa advokat serta eksekutif BMT. Kemampuan legal drafting memang dibutuhkan bagi alumni HES agar bisa berkiprah dan berkontribusi signifikan ketika mendapatkan posisi pada legal department dari suatu LKS.

Temuan menarik lainnya adalah hukum pidana yang hanya mendapat prioritas urutan terakhir. Hanya satu hingga dua pakar yang memberi masukan bahwa hukum pidana tetap penting dipelajari karena untuk menjadi advokat kompetensi yang diuji adalah menyeluruh, termasuk hukum pidana. Seluruh hakim yang diwawancarai mengeluh terkait kasus-kasus ekonomi syariah yang harus berujung di meja hijau. Mereka menyoroti fungsi arbitrase yang sangat tidak signifikan. Responden hakim Pengadilan Agama Klaten menyatakan bahwa value unggulan ekonomi syariah adalah musyawarah yang hal itu seharusnya terwujud pada arbitrase. Fungsi arbitrase yang kurang membuat value tersebut tidak muncul.

6. Kompetensi Komplementari Hukum

Tabel 7. Hasil hitung pada kelompok Kompetensi Komplementari Hukum

\begin{tabular}{llc}
\hline Elemen & Nilai & Ranking \\
\cline { 2 - 3 } Etika Profesi Hukum & 0.229 & 1 \\
Filsafat Hukum & 0.199 & 3 \\
Metlit Kuantitatif & 0.173 & 5 \\
Sjrh Hukum Islam & 0.184 & 4 \\
Catatan: & 0.213 & 2 \\
\cline { 2 - 3 } & Silai Kendallogi Hukum & \multicolumn{1}{c}{ Kend coeifficient (W) untuk rater agreement adalah 0.056}
\end{tabular}

Sebagai mahasiswa yang akan mendapat gelar Sarjana Hukum ketika lulus, pakar menilai ada beberapa hal tambahan yang perlu juga dibekalkan kepada mahasiswa. Berdasarkan observasi pada awal penelitian, sejumlah Komplementari Hukum yang selalu ada pada berbagai kampus adalah Metodologi Penelitian Hukum dan Kualitatif. Hasil riset menunjukkan bahwa prioritas pertama adalah Etika Profesi Hukum dengan nilai 0.229. Pakar advokat dan hakim menekankan etika profesi ini dikarenakan banyak advokat maupun hakim yang kehilangan integritasnya. Alumni HES seharusnya jauh lebih memilik integritas karena dididik dalam nuansa Islam. Adapun Metodologi Kuantiatif mendapat prioritas terakhir dengan nilai 0.173. Hal ini menunjukkan bahwa pembekalan teknik-teknik penelitian kuantitatif kepada mahasiswa tidak terlalu relevan. 
Fauzul Hanif Noor Athief, Azhar Alam, Nurul Latifatul Inayati

Pada wawancara bersama pengacara senior di Jakarta, responden tersebut menekankan aspek etika profesi hukum yang tidak terlalu nampak pada para pengacara. Ketua APSI pun menyatakan bahwa etika ini penting diperkuat, karena jika tidak, dikhawatirkan banyak kepentingan tergadaikan oleh hal-hal materiil.

7. Profil Lulusan

Tabel 8. Hasil hitung pada kelompok Profil Lulusan

\begin{tabular}{lcc}
\hline Elemen & Nilai & Ranking \\
\hline Asisten Peneliti & 0.180 & 2 \\
Dewan Pengawas Syariah & 0.169 & 3 \\
Hakim & 0.194 & 1 \\
Pengacara & 0.164 & 4 \\
Penyuluh & 0.131 & 6 \\
Praktisi LKS & 0.159 & 5 \\
\hline Nilai Kendalls' coeifficient (W) untuk rater agreement adalah0.476
\end{tabular}

Para pakar juga disurvey terkait profil lulusan apa yang paling tepat dengan berbagai aspek mata kuliah. Rater agreement menunjukkan bahwa separuh dari pakar (0.476) selalu bersepakat dalam jawaban-jawaban survey. Para pakar yang merupakan stakeholder dari program studi HES mengatakan bahwa profesi hakim adalah prioritas utama dengan seluruh mata kuliah di atas. Artinya para stakeholder berharap bahwa alumni HES dapat mengisi ruang-ruang meja hijau sebagai pengambil keputusan. Yang menarik, Asisten peneliti justru mendapat prioritas kedua dengan nilai 0.180. Biasanya profil asisten peneliti selalu menjadi urutan terakhir dalam KKNI Kemenag. Akan tetapi ternyata para stakeholder pakar mengatakan sebaliknya.

Pada prioritas ketiga dan keempat ada DPS dan pengacara. Keduanya mempunyai nilai yang hampir sama. Pengacara yang biasanya merupakan lahan profesi paling menarik selain hakim ternyata hanya berada pada prioritas keempat.DPS lebih penting dari pada profesi advokat. Akan tetapi prioritas kelima dan keenam yaitu praktisi LKS dan penyuluh memberikan arahan lebih kepada para pelaksana pada program studi HES. Bahwasanya menjadi praktisi LKS bukanlah prioritas utama bagi para stakeholder, terlebih lagi menjadi penyuluh pada Kantor Urusan Agama.

8. Peningkatan

Tabel 9. Hasil hitung pada kelompok Peningkatan

\begin{tabular}{lcc}
\hline Elemen & Nilai & Ranking \\
\hline Pelatihan & 0.231 & 3 \\
Penelitian & 0.190 & 4 \\
Perkuliahan & 0.292 & 1 \\
Praktik & 0.285 & 2 \\
\hline : Nilai Kendalls' coeifficient (W) untuk rater agreement adalah0.42
\end{tabular}

Penelitian ini juga menanyakan peningkatan yang perlu dilakukan agar para alumni HES bisa mencapai profil lulusan sebagaimana diharapkan oleh para stakeholder. Dengan kesepakatan antar pakar mencapai hampir setengah (0.42), maka hasil penelitian menunjukkan bahwa para 
pakar mempunyai pemikiran yang cukup seragam. Prioritas utama adalah perkuliahan. Seluruh pakar mengatakan bahwa perkuliahan tetap penting karena dasar-dasar ilmu pengetahuan didapatkan dari sana. Pengalaman kerja memang akan mempertajam kemampuan alumni, tetapi tidak akan membekali mereka dari nol. Dari sini bisa dipahami bahwa proses pembelajaran di dalam kelas harus lebih diperbaiki lagi untuk membekali para mahasiswa dengan ilmu yang cukup sebelum terjun ke dunia profesi.

Pada prioritas kedua adalah praktik. Pada sela-sela survey para pakar mengatakan bahwa untuk mendalami profesi sebagai sarjana hukum harus memperbanyak praktik. Hal ini sejalan dengan hasil survey kuantitatif sebagaimana ditunjukkan pada Tabel 9. Praktik yang dimaksudkan di sini bisa dalam dua bentuk sebagaimana dijelaskan para pakar. Pertama adalah praktik yang masuk di dalam kurikulum pembelajaran dan yang kedua adalah praktik pasca seorang mahasiswa lulus dan mendapat gelar S.H. Artinya agar menjadi mahir dalam profesi-profesi pada Tabel 8, maka selain kuliah pembekalan utamanya adalah praktik. Kuliah dan praktik ini harus beriringan sebagaimana terlihat bahwa nilai hasil survey antara keduanya berbeda sangat tipis yaitu 0.292 dan 0.285 secara berurutan. Aspek yang paling tidak menjadi prioritas adalah penelitian dengan nilai terpaut jauh dari prioritas ketiga, yaitu 0.19.

\section{E. Diskusi : Kurikulum Program Studi PTKI dan Kebutuhan Masyarakat}

Di Indonesia, hukum yang berlaku adalah hukum positif dengan karakteristiknya yaitu bisa dibuktikan (verifiable), terukur (measurable) dan dapat diamati (observable). Maka dari itu, untuk menjadi seorang konsultan hukum di Indonesia maka harus mengikuti aturan-aturan yang berlaku, di antaranya menempuh pendidikan formal yang substansi perkuliahannya mengandung materi hukum. Program studi Hukum Ekonomi Syariah maupun Hukum Bisnis Syariah sendiri merupakan perubahan dari program studi muamalah untuk dapat memenuhi standar kualifikasi seorang sarjana dapat berkecimpung dalam bidang hukum di Indonesia. Perubahan nomenklatur ini dibarengi dengan perubahan gelar dari Sarjana Hukum Islam, ${ }^{35}$ menjadi Sarjana Syariah ${ }^{36}$ dan terakhir menjadi Sarjana Hukum ${ }^{37}$. Yasin menyatakan perubahan gelar yang bermuara akhir menjadi Sarjana Hukum mempunyai aspek politik hukum ${ }^{38}$ yang tujuannya adalah penyetaraan alumni agama Islam di mata masyarakat.

Perubahan gelar dan nomenklatur ini tentunya harus dibarengi dengan penyesuaian kurikulum agar lulusan Hukum Ekonomi Syariah benar-benar menjadi SDM memberi kontribusi lebih bagi masyarakat. Menjawab dan melanjutkan hasil penelitian Zainuddin terkait kurikulum sebagai faktor penghambat SDM Hukum Ekonomi Syariah, hasil statistik pada penelitian ini

\footnotetext{
35 Keputusan Direktur Jenderal Kelembagaan Agama Islam Departemen Agama Republik Indonesia Nomor: E/10/ Tahun 2002 Tentang Gelar dan Sebutan Lulusan Perguruan Tinggi Agama Islam.

36 Peraturan Menteri Agama Nomor 36 Tahun 2009 Tentang Penetapan Pembidangan Ilmu dan Gelar Akademik di Lingkungan Peguruan Tinggi Agama

${ }^{37}$ Peraturan Menteri Agama Nomor 33 Tahun 2016 Tentang Tentang Gelar Akademik Peguruan Tinggi Keagamaan

${ }^{38}$ M. N Yasin, "Politik Hukum Pemberlakuan Gelar" Sarjana Hukum" Untuk Alumni Jurusan Hukum Bisnis Syariah,"
} 
Fauzul Hanif Noor Athief, Azhar Alam, Nurul Latifatul Inayati

memberikan gambaran lebih. Pertama, penekanan pada aspek materi hukum adalah mutlak disepakati oleh berbagai stakeholder. Hasil ini sejalan dengan kesimpulan penelitian Zainuddin yang melakukan ekplorasi datanya dengan cara wawancara bahwa muatan hukum pada kurikulum harus diperbanyak. ${ }^{39}$ Selanjutnya, penekanan para stakeholder pada aspek ekonomi yang menjadi prioritas kedua merupakan jawaban dari fakta lapangan bahwa tenaga SDM yang terjun di berbagai lembaga keuangan syariah masih sangat minim dengan kebutuhan yang terus bertambah. Hal ini juga sejalan dengan ucapan Sri Mulyani, Menteri Keuangan periode 2020-2024 yang menyebutkan bahwa SDM yang ada pada lembaga keuangan syariah saat ini justru bukan berasal dari program studi yang diharapkan mengisi ruang-ruang SDM tersebut. ${ }^{40}$ Lain dari pada itu, hasil statistik terkait urgensi fikih juga menguatkan pendapat Ardiansyah terkait banyaknya SDM lembaga keuangan syariah justru adalah pindahan bank konvensional tanpa penguasaan mendalam terhadap ilmu dasar fikih, usul fikih dan ilmu syariah terkait.41

Detail hasil statistik terkait tingkatan urgensi mata kuliah sebagai bekal mahasiswa Hukum Ekonomi Syariah di masyarakat memberikan gambaran tambahan bagi institusi pendidikan untuk mengambil keputusan mata kuliah apa saja yang penting dimasukkan dalam silabus pembelajaran. Misalnya dalam aspek ekonomi Islam, ternyata kemampuan melakukan analisa laporan keuangan menjadi sorotan utama, sedangkan sejarah tidak mendapat perhatian banyak dari para stakeholder. Kemudian dalam aspek fikih, kajian fatwa ternyata mendapat respon persepsi urgensi tertinggi baik secara kuantitatif statistik maupun hasil kualitatif wawancara. Di sisi lain, fikih munakahat yang bukan menjadi kompetensi utama Hukum Ekonomi Syariah mendapatkan penekanan bahwa mata kuliah ini adalah tidak lain hanya tambahan pelengkapan wawasan hukum Islam. Contoh lain adalah detail pada mata kuliah hukum, ternyata justru arbitrase yang jarang dimasukkan sebagai mata kuliah pada prodi Hukum Ekonomi Syariah mempunyai urgensi sangat tinggi, sedangkan mata kuliah hukum pidana dipandang tidak terlalu relevan untuk dibekalkan kepada mahasiswa.

Seluruh hasil temuan di atas memberi tambahan sudut pandang dalam pembuatan konstruksi kurikulum Hukum Ekonomi Syariah. Kurikulum yang ada saat ini sangat bervariasi antara satu kampus dengan yang lain. Fakta di lapangan menunjukkan perbedaan antar kampus sangat besar meskipun Direktorat Pendidikan Tinggi Agama Islam telah merumuskan SKL dan CPL yang dibutuhkan. Penulis pribadi melakukan telaah tambahan terhadap kurikulum dari berbagai universitas termasuk di antaranya adalah UIN Jogja, IAIN Salatiga, UIN Malang, IAIN Pekalongan serta UIN Palembang. Dari telaah sederhana, didapati bahwa jumlah mata kuliah dengan aspek ilmu Islam termasuk fikih dan usul fikih bervariasi dari 10 hingga 25 mata kuliah. Untuk mata kuliah

\footnotetext{
${ }^{39}$ Zainuddin, "Peluang Dan Tantangan Sarjana Syariah Dalam Menggeluti Profesi Advokat Pasca Undang-Undang Nomor 18 Tahun 2003: Studi Kasus Di Banda Aceh Dan Aceh Besar."

40 https://bisnis.tempo.co/read/1418561/sri-mulyani-ungkap-90-persen-sdm-di-industri-keuangan-syariahdari-prodi-berbeda/full\&view=ok diakses pada Jumat, 12 Maret 2021 pukul 08.39 WIB.

41 M Ardiansyah, I Qizam, and J Setyono, "Konstruksi Kompetensi Profesional Sarjana Ekonomi Syariah pada Lembaga Keuangan Syariah,"
} 
ekonomi yang ditawarkan bervariasi dari 2 hingga 13. Hanya mata kuliah hukum yang mempunyai variasi rendah yaitu 29 hingga 34 mata kuliah. ${ }^{42} \mathrm{Hal}$ ini belum terhitung mengenai diversitas nama dan materi mata kuliah yang ditawarkan. Tentu keseragamaan bukanlah hal yang diinginkan mengingat setiap kampus dan program studi mempunyai karakteristik pembeda masing-masing, akan tetapi tentu dibutuhkan kompetensi pokok yang seragam. Hal ini untuk menjamin bahwa mahasiswa mendapat materi-materi yang memang urgen untuk diterapkan di masyarakat sesuai gelar sarjananya, dan bukan justru mendapat materi yang sifatnya terlalu umum tidak spesifik pada satu bidang ilmu.

Keberhasilan program studi untuk merumuskan mata kuliahnya berbasis kebutuhan masyarakat akan jauh membawa para alumni terserap dan berkontribusi terhadap masyarakat. Meskipun belum ada penelitian empiris terdahulu pada bidang ilmu syariah terkait penyerapan alumni ini, tetapi berbagai bidang ilmu lain di berbagai negara telah membuktikannya. ${ }^{43,44}$ Maka dari itu hasil studi ini tentu bisa dijadikan basis pengambilan kebijakan dalam pembuatan kurikulum bagi seluruh prodi Hukum Ekonomi Syariah pada Perguruan Tinggi Keagamaan Islam di Indonesia. Terlebih lagi tenaga syariah yang pada 2015 sempat diprediksi bahwa akan dibutuhkan hingga 40.000 tenaga SDM syariah pada tahun berikutnya sudah jauh bertambah. ${ }^{45}$ Hal ini karena masuknya perkara perdata ekonomi syariah ke lingkup Pengadilan Agama, menjamurnya BMT, bertambahnya BPR syariah dan berbagai lembaga keuangan syariah lain yang tentuya memerlukan Dewan Pengawas Syariah. Belum lagi dengan kebijakan wajib sertifikat halal berdasarkan UU 33/2014 tentang Jaminan Produk Halal, serta diluncurkannya inovasi keuangan baru oleh OJK yaitu equity crowd funding, security crowd funding dan berbagai inovasi lain, maka sesungguhnya prodi Hukum Ekonomi Syariah mempunyai kewajiban serta kesempatan untuk memberikan pendidikan terbaik bagi mahasiswanya agar bisa bermanfaat dan terserap oleh kebutuhan masyarkat.

\section{F. Kesimpulan}

Ekosistem ekonomi syariah perlu didukung oleh banyak infrastruktur di dalamnya, termasuk proses penyiapan SDM yang relevan dan dibutuhkan oleh stakeholder. Menariknya, banyak penelitian maupun opini pakar pada media massa yang menyebutkan bahwa alumni Hukum Ekonomi Syariah banyak yang tidak terserap ke dalam industri. Perhatian para stakeholder jatuh pada lembaga penyedia pendidikan, khususnya terkait kurikulum yang diharapkan mampu membantu para alumni untuk bisa terjun dan bersaing di dunia profesi hukum. Berbagai penelitian

\footnotetext{
42 Telaah dilakukan berdasarkan sebaran mata kuliah yang bisa diakses dari website masing-masing prodi pada universitas yang disebutkan.

${ }^{43}$ E Ishengoma and T. I. Vaaland, "Can University-Industry Linkages Stimulate Student Employability?,"

44 D. H. Lee et al., "Development of Partnership between Industry and University via Customized Field-Oriented Curriculum,"

45 M Ardiansyah, I Qizam, and J Setyono, "Konstruksi Kompetensi Profesional Sarjana Ekonomi Syariah pada Lembaga Keuangan Syariah,"
} 
Fauzul Hanif Noor Athief, Azhar Alam, Nurul Latifatul Inayati

telah menemukan bukti secara empirik bahwa kurikulum yang baik benar-benar membantu alumni untuk dapat terserap sebagai tenaga kerja di dunia industri.

Penelitian ini mendapati bahwa dari 5 aspek kurikulum yaitu Kompetensi Bahasa, Kompetensi Hukum, Kompetensi Fikih, Kompetensi Ekonomi Islam, Kompetensi Komplementari Hukum, para pakar menyatakan prioritas utama adalah pembekalan mahasiswa pada aspek Kompetensi Hukum. Kemudian terkait mata kuliah tambahan di luar kompetensi utama yang telah disepakati seluruh kampus, penelitian ini mendapati bahwa untuk Kompetensi Bahasa, kemampuan Arab Dasar merupakan prioritas tertinggi. Pada Kompetensi Ekonomi Islam, Analisa Laporan Keuangan sangat diharapkan oleh pakar ditambahkan sebagai bagian penting dari kurikulum. Para pakar juga berharap Kajian Fatwa ditekankan sebagai bagian dari Kompetensi Fikih. Kemampuan Arbitrase juga menjadi sorotan utama untuk Kompetensi Hukum, di samping Kompetensi Komplementari Hukum dan Etika Profesi Hukum.

Alumni program Hukum Ekonomi Syariah sangat diharapkan oleh pakar untuk berprofesi sebagai hakim dengan seluruh mata kuliah yang telah disebutkan di atas. Adapun untuk dapat mencapai seluruh profil lulusan, para pakar sepakat bahwa proses perkuliahan adalah hal terpenting bagi para alumni. Praktik kerja lapangan (PKL) atau magang dan sejenisnya perlu dilaksanakan setelah kuat dalam pemahaman teoretik di perkuliahan.

\section{G. Referensi}

Abas-Mastura, M, O. A. Imam, and S Osman, 'Employability Skills and Task Performance of Employees in Government Sector', International Journal of Humanities and Social Science, 3.4 (2013), 150-62

Abbasi, F. K., A Ali, and N Bibi, 'Analysis of Skill Gap for Business Graduates: Managerial Perspective from Banking Industry', Education+ Training, 60.4 (2018), 354-67

Akhtyamova, N, M Panasyuk, and R Azitov, 'The Distinctive Features of Teaching of Islamic Economics: Philosophy, Principles and Practice', Procedia - Social and Behavioral Sciences, 191 (2015), 233438

Amalia, E, and M. N. R. Al Arif, 'Kesesuaian Pembelajaran Ekonomi Islam Di Perguruan Tinggi Dengan Kebutuhan Sdm Pada Industri Keuangan Syariah Di Indonesia', INFERENSI: Jurnal Penelitian Sosial Keagamaan, 7.1 (2013), 123-42

Ardiansyah, M, I Qizam, and J Setyono, 'Konstruksi Kopetensi Profesional Sarjana Ekonomi Syariah Pada Lembaga Keuangan Syariah', INFERENSI: Jurnal Penelitian Sosial Keagamaan, 7.1 (2013), 99-122

Ascarya, Analytic Network Process (ANP): Pendekatan Baru Studi Kualitatif (Jakarta: Pusat Pendidikan dan Studi Kebanksentralan, Bank Indonesia., 2005)

Ascarya, and D Yumanita, Determinan Dan Persistensi Margin Perbankan Konvensional Dan Syariah Di Indonesia, 2010

Ayoubi, R. M., K Alzarif, and B Khalifa, 'The Employability Skills of Business Graduates in Syria: Do Policymakers and Employers Speak the Same Language?', Education+ Training, 59.1 (2017), 6175

Aziz, I. J., 'Analytic Network Process With Feedback Influence: A New Approach to Impact Study', in Analytic Network Process With Feedback Influence: A New Approach to Impact Study (University of Illinois at Urbana-Champaign, 2003) 
Belabes, A, A Belouafi, and M Daoudi, 'Designing Islamic Finance Programmes in a Competitive Educational Space: The Islamic Economics Institute Experiment', Procedia-Social and Behavioral Sciences, 2015, 639-43

Boersma, F. K., C. J. Reinecke, and M. Gibbons, 'Organizing the University-Industry Relationship: A Case Study of Research Policy and Curriculum Restructuring at the North-West University in South Africa', Tertiary Education and Management, 14.3 (2008), 209-26 <https://doi.org/10.1080/13583880802228216>

Brimble, P, and R. F. Doner, 'University-Industry Linkages and Economic Development: The Case of Thailand', World Development, 35.6 (2007), 1021-36

Daud, S, N Abidin, M. N. Sapuan, and J Rajadurai, '). Enhancing University Business Curriculum Using an Importance-Performance Approach: A Case Study of the Business Management Faculty of a University in Malaysia.', International Journal of Educational Management, 25.6 (2011), 545-69

Guimon, J, 'Promoting University-Industry Collaboration in Developing Countries', World Bank, 3 (2013), 12-48

Ishengoma, E, and T. I. Vaaland, 'Can University-Industry Linkages Stimulate Student Employability?', Education+ Training, 58.1 (2016), 18-44

Laguador, J. M., and L. R. Ramos, 'Industry-Partners' Preferences for Graduates: Input on Curriculum Development', Journal of Education and Literature, 1.1 (2014), 1-8

Lee, D. H., K. H. Jung, K Yi, Y. S. Cho, Y. S Han, and D. C Kang, 'Development of Partnership between Industry and University via Customized Field-Oriented Curriculum', in 2005 IEEE International Conference on Microelectronic Systems Education (MSE'05) (IEEE, 2005), pp. 81-82

Lee, J, and H. N Win, 'Technology Transfer between University Research Centers and Industry in Singapore', Technovation, 24.5 (2004), 433-42

Marshall, M. N., 'Sampling for Qualitative Research', Family Practice, 13.6 (1996), 522-26

McQuaid, R. W., and C Lindsay, 'The Concept of Employability', Urban Studies, 42.2 (2005), 197-219

Pilgrim, C. J, 'Industry Involvement in ICT Curriculum: A Comparative Survey.', in Proceedings of the 2013 International Conference on Software Engineering (IEEE Press, 2013), pp. 1148-53

Rosman, E, 'Urgensi Pengacara Syari'ah Dalam Penegakan Hukum Di Indonesia (Studi Analisis Partisipatoris Sarjana Syari'ah Dimasa Datang)', ALHURRIYAH: Jurnal Hukum Islam (ALHURRIYAH JOURNAL OF ISLAMIC LAW), 16.1 (2018), 79-94

Saaty, T. L., Fundamentals of Decision Making (Pittsburgh: RWS Publication, 1994)

Saaty, T. L., and L. G. Vargas, Decision Making with the Analytic Network Process: Economic, Political, Social and Technological Applications with Benefits, Opportunities, Costs and Risks (New York: Springer Science + Business Media, 2006)

Sari, N, 'Re-Design Kurikulum Ekonomi Syariah Perguruan Tinggi Agama Islam', Jurnal Ilmiah Peuradeun, 2.3 (2014), 135-54

Small, M. L., 'How Many Cases Do I Need? On Science And The Logic Of Case Selection In Field-Based Research', Ethnography, 10.1 (2009), 5-38

Suryanti, S., A Ibrahim, and A Ayumiati, 'Analisis Kompetensi Kurikulum Prodi Perbankan Syariah Uin Ar-Raniry Banda Aceh Dan Kesesuaiannya Dengan Kebutuhan Bank Syariah.', JIHBIZ: Global Journal of Islamic Banking and Finance., 1.1 (2019)

Tessema, B. S., and S. B. Abejehu, 'University-Industry Collaboration in Curriculum Development: Analysis of Banking and Finance Graduates' Attributes from Educators and Industries Perspective', Education Journal, 6.2 (2017), 87-93 
Turnip, I. R. S, and A Hayati, Akseptabilitas Sarjana Hukum Islam Pada Seleksi Calon Hakim Peradilan Agama Di Mahkamah Agung RI Tahun 2017 (Bandung: Mujahid Press, 2019)

Walker, K. B., and E. L. Black, 'Reengineering the Undergraduate Business Core Curriculum: Aligning Business Schools with Business for Improved Performance', Business Process Management Journal, 6.3 (2000), 194-213

Yasin, M. N, 'Politik Hukum Pemberlakuan Gelar" Sarjana Hukum" Untuk Alumni Jurusan Hukum Bisnis Syariah', Jurisdictie: Jurnal Hukum Dan Syariah, 7.2 (2016), 168-89

Zainuddin, M, 'Peluang Dan Tantangan Sarjana Syariah Dalam Menggeluti Profesi Advokat Pasca Undang-Undang Nomor 18 Tahun 2003: Studi Kasus Di Banda Aceh Dan Aceh Besar', Petita: Jurnal Kajian Ilmu Hukum Dan Syariah, 1.1 (2017), 117-33 